\title{
ランのノートル＝ダム大聖堂における現場組織の変化について
}

トリフォリウムへの立入調査の意義と可能性

\section{THE CHANGES IN ORGANIZATION OF THE WORK SITE AT THE NOTRE-DAME CATHEDRAL OF LAON}

The importance and the possibilities of studying the triforium

$$
\begin{gathered}
\text { 嶋 崎 } \quad \text { 礼 }^{* 1} \\
\text { Aya SHIMAZAKI }
\end{gathered}
$$

The interior of the triforium is rarely studied despite rich information it contains. This paper takes the case of Laon Cathedral to show how the study of the triforium can be fruitful. Though the elevation may not change through its construction, technical details of the triforium may reveal the changes in organization of the work site. In Laon Cathedral, the masonry techniques, the masons' marks and the putlog holes (trou de boulin) suggest that it have changed twice.

\section{Keywords : Gothic architecture, Laon Cathedral, Triforium, Work site} ゴシック建築, ラン大聖堂, トリフォリウム, 建設現場

\section{1. はじめに}

トリフォリウム（triforium）は、ゴシック建築の内部立面の中間 に位置する、壁の厚みの中の通路のことで、背の低いアーケードに よって主廊に開いている。建設当時からその内部に人が立ち入るこ とはめったになかったと思われる。近代以降も通路への立ち入りを 伴う考古学的な調査はほとんど行われてこず、もっぱらその立面の

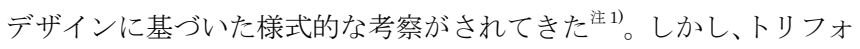
リウムは壁内通路という複雑な構造をもち、構成部材も多様である ことから、建設工期の切り替わりを反映するディテールの変化や、 建設技術を知る手がかりが見つかる可能性がある。特に建設に関す る一次史料が極めてそしい中世建築の研究においては、トリフォリ ウムの調査は有意義な成果をもたらすことが期待される。本稿はラ
ン大聖堂（Fig.1）を取り上げ、トリフォリウムへの立入調査がどの ような新たな知見を提供しうるかを例示し、それを通じてトリフォ リウム調查の意義と可能性を示寸ことを意図している。調查の成果 は本稿で示す「現場組織の変化を明らかにする」ことにとどまらな いが、紙幅の都合上、本稿で提示する知見はこの目的に資するもの に限定し、その他の観察については場を改めて整理したい。

ラン（Laon）はパリの北東約 120 キロメートル、エーヌ川沿いの 都市ソワッソンの近郊に位置する。小高い丘の上に建設された城塞 都市であり、ノートル＝ダム大聖堂や複数の旧修道院建築をはじめ 中世以来の遺構が豊富に残されている。

大聖堂のトリフォリウムは等間隔の三連アーケードであり、現存
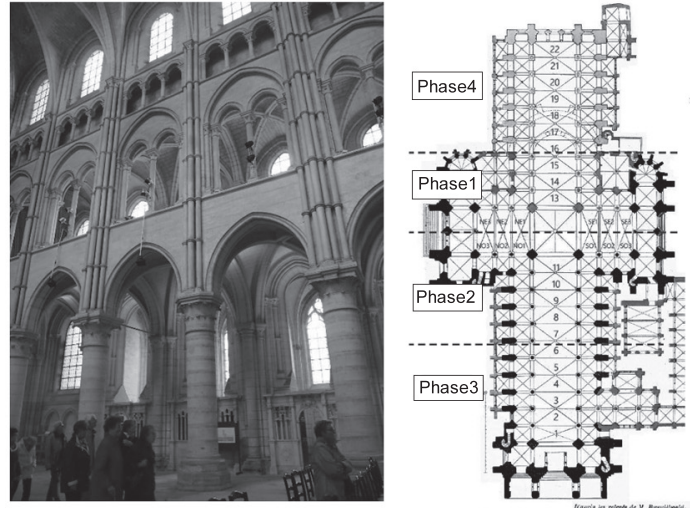

Fig.1 Laon Cathedral, interior view Fig.2 Plan (Bouxin/author)

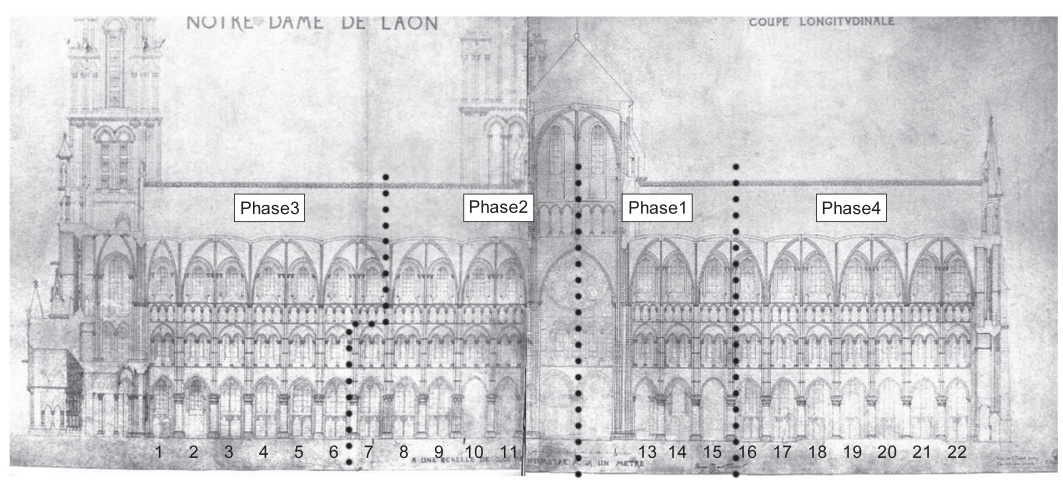

Fig.3 Longitudinal section (MAP cote 0082/002/1016, no. 004008)

*1 東京大学大学院工学系研究科建築学専攻 学術支援職員 . 工博

Research Assist. Staff, Dept. of Architecture, Graduate School of Engineering, The University of Tokyo, Dr.Eng. 
するゴシック建築における最初期のトリフォリウムのひとつとして

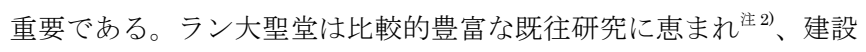
段階も明確に見定められているが、トリフォリウムの詳細な調査は まだ行われていない。ラン大聖堂の主要部分は 12 世紀半ばから 13 世紀初頭まで、半世紀以上の時間をかけて建設されたが、内部立面 はほとんど変化することなく完成した（Fig.3）。しかしながら工事 がある程度一貫した体制のもと進められたのか、あるいはそれぞれ 先行する工期の立面を継承しつつ現場組織が变化していったのかに ついては検討されてこなかった。建設に要した時間からして途中で 工匠や職人が変化したことは明白であるが、そのタイミングは明ら かにされていない。本研究はトリフォリウムに観察される建設手法 の変化から、現場組織がいつ変化したかを検討するものである。各 工期で作業に当たった職人はそれぞれある程度独自の建設手法を有 していたはずであり、トリフォリウム内部にそれを知る手がかりが 残されている可能性がある注3)

そのためにまず建設過程を整理し (2 章)、トリフォリウム内部に 見られる技術的特徴を整理する (3・4 章)。その上で、現場組織が 大きく変化したタイミングに関して、仮説を立てる。

なお、ラン大聖堂は 19 世紀半ばから 20 世紀半ばにかけて大々的

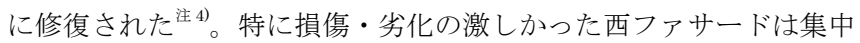
的に修復、補強工事が行われた。ファサードに隣接する身廊のベイ $2 \sim 4$ はトリフォリウムを含めほぼ完全に再建されたが、それ以外 のベイは組積の一部のブロックを同形状の新しい石材で置き換える ような修復にとどまっており、調査に特に支障はない。取り替えら れたブロックはその真新しい色から容易に識別可能である。

\section{2. エ期の切れ目一ラン大聖堂の建設過程}

本章では、先行研究を参照しつつ、トリフォリウム内の石積みの 切れ目や柱頭彫刻を手がかりとすることで、建設過程を 4 つの工期 として整理する（Fig.2,3）。なお、本研究は建設過程そのものの再考 を目的としているのではなく、トリフォリウムの調査を通じてそれ に新たな視点を加えることを狙っている。

\section{工期 1 （1150 年頃〜 1164 年頃 $)$}

現在のラン大聖堂の建物は、1112 年の火災の後に修復された 9 世 紀の建物を建て直す形で、1150 年頃着工したとみられる。工事は内

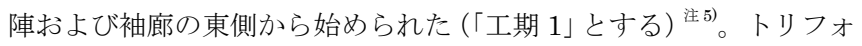
リウムの背後の壁において、ベイ $\mathrm{N} 15 \cdot \mathrm{N} 16$ 間と $\mathrm{S} 15 \cdot \mathrm{S} 16$ 間のピ アの背後に、明確な石積みの切れ目がある (Fig.4, 5)。

発掘調查から、当初の内陣は 3 ベイの直線ベイに放射祭室のない
周歩廊のついた半円形アプスが接続したものであったことが判明し ている注6)。トリフォリウムのベイ $15 ・ 16$ (ベイ番号は Fig.15 参照) 間のピアの背面では、アバクスから連続する剞り型がやや湾曲して

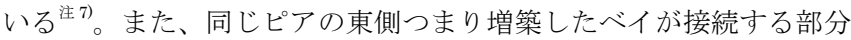
では、隣接する小円柱のアバクスやトリフォリウムの上下を走るコー ニスが壁に対しやや斜めに突き出ているのが確認される。これらの 痕跡は、半円形アプスの古い内陣がちょうどこの位置を境に取り壊 されたことを示している。

トリフォリウムの柱頭を見ると、内陣のベイ $13 \sim 16 \cdot \mathrm{S} 17$ と袖 廊東側では、ヴァリエーションに富む複雑な葉模様や組紐模様の彫 刻が施されている。同じ工期のトリビューンにも同様の柱頭彫刻が 見られる。柱礎に蹴爪飾り（griffe）があるのも特徴である（この部 分以外のほとんどの柱礎には蹴爪飾りがない）（Fig.8）。ベイ N16・ $\mathrm{S} 16 \cdot \mathrm{S} 17$ は後の拡張工事で付け足された部分に属するが、ベイ 13 〜 15 同様の複雑な装飾が施されている。これは取り壊された 12 世 紀の半円形アプスの石材が再利用されているためだと考えられる注 8)。内陣の拡張工事は主にシェルミジの石切り場の石材を用いている が注9)、取り壊された半円形アプスの石材も数多く再利用されたよう だ。ただしトリフォリウム内の柱で再利用されているものはこれら のベイの独立柱のみであり、ピアに隣接する小円柱の柱頭は 13 世 紀のピアと一体のブロックで成形されているため、再利用材ではな い(ベイ 16 の西端の小円柱は拡張時も取り除かれなかったため 12 世紀のままである)。柱基も再利用されていると思われ、いずれも蹴 爪飾りのある柱礎を有する。

以上の観察から、工期 1 は袖廊東側（ $\mathrm{NE} 1 \sim 3, \mathrm{SE} 1 \sim 3 ）$ と内 陣べイ $13 \sim 15$ と定められる。

\section{工期 2（1164 年頃 1185 年頃)}

続いて南北袖廊の祭室や袖廊の西側、身廊の東側が建設された。 この段階で袖廊の祭室の拡大や袖廊の塔の建設など、重要な計画変 更が行われたとみられる。クラークとキングによれば、1185 年頃ま でに袖廊が完成し、身廊の地上階とトリビューン階は東側 5 ベイま で進んだ。一方でトリフォリウム階は 4 ベイまでで一旦工事が中断 したとみられる注 10)。というのも、トリフォリウム背後の壁の切れ目 はベイ N7 の東側（Fig.6）にあるからだ。S7の切れ目は北側 N7 に 比べ不明瞭であるものの、石積みの高さの変化が認められる（Fig.7）。

袖廊西側と身廊のベイ $8 \sim 11$ の柱頭彫刻は、葉の本体が著しく 平面的で、クロシェ（葉の先端の丸まった部分）が小さく単純である。 なお、アバクスの背面（通路側の面）は荆り型が施されず平坦で、アー チの背面と同一平面上にある。
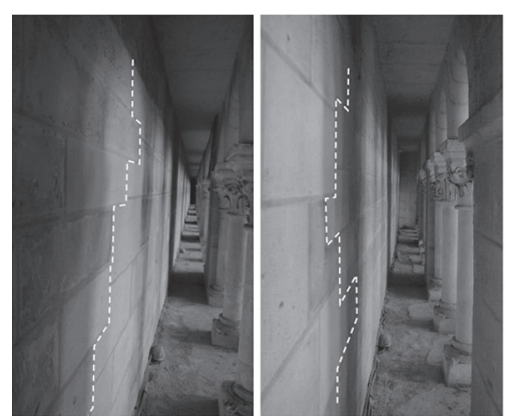

Fig. 4 bay N15/N16 Fig. 5 bay S15/S16

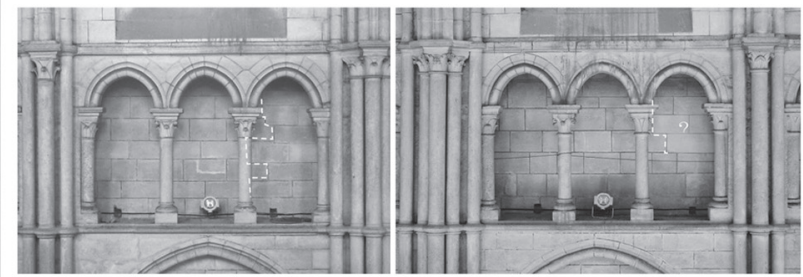

Fig. 6 bay $\mathrm{N} 7$ (broken lines by author)

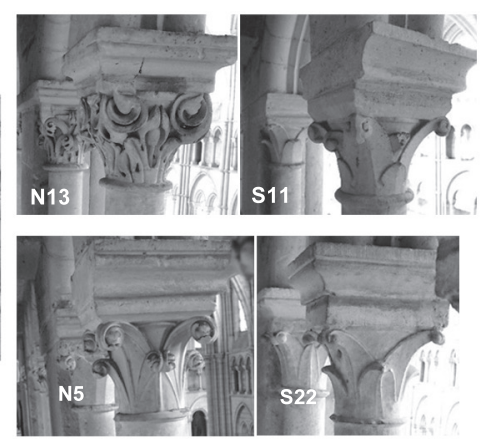

Fig.8 Capital sculptures 


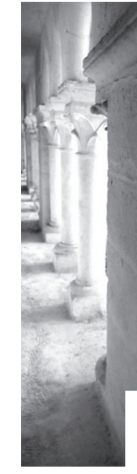

Fig. 9 Choir, S19 (by author)

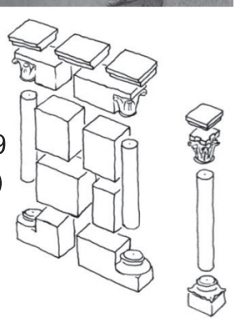

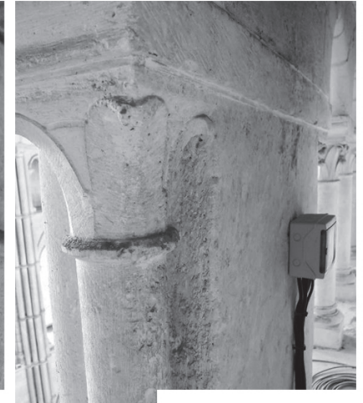

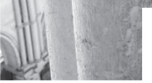

Fig.10 $\mathrm{N}$ side of the nave (by author)

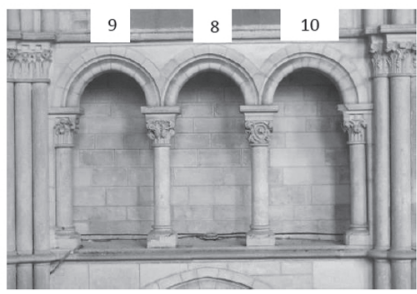
-N15 Phase 1

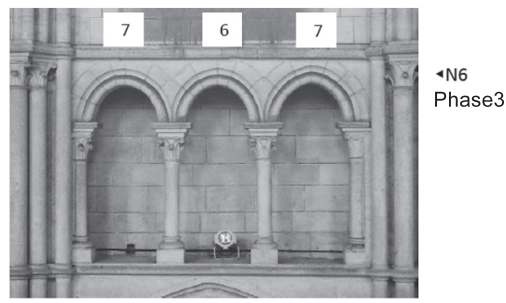

Fig.11 Number of voussoirs
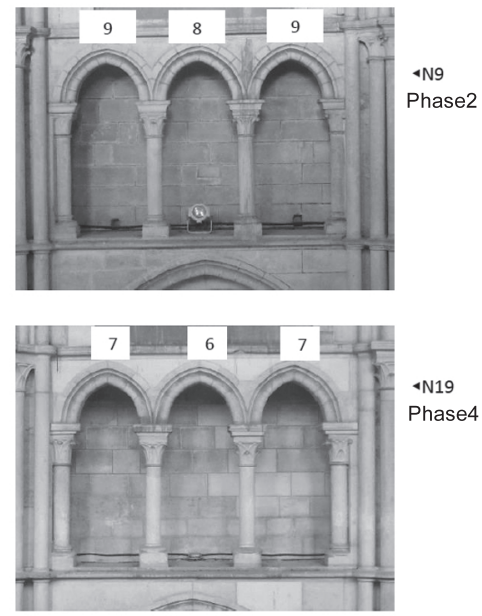

4 N19

\section{工期 3 （1185 年頃 1200 年頃 $)$}

続いて身廊の西側および西ファサードが建設され、建物全体は 1200 年頃までに一通り完成したとみられる ${ }^{\text {注 }}{ }^{11}$ 。

ベイ $5 \sim 7(2 \sim 4$ は 19 世紀の再建のため考慮しない）の柱頭彫 刻は、工期 2 に比べ葉の本体がより立体的で、クロシェもより彫塑 的な傾向が認められる。アバクスの背面はやはり平坦である。

工期 2 と 3 の区別はやや不明瞭であるが、石積みの切れ目があり、 柱頭彫刻にも個性が認められることから、独立した工期と考えられ る。

\section{工期 4 (1205 年頃 )}

内陣の拡張は 13 世紀初頭に行われた。1205 年付けで記録されて いるシェルミジの石切り場の寄進が、年代の目安となる注12)。アプス と周歩廊が取り壊され、8つの直線ベイが古い内陣の直線 3 ベイに 接続された。建設間もない内陣を一部取り壊してまで拡張した理由 としては、当時のラン大聖堂にはパリ大聖堂のそれを上回る参事会 員がおり、手狭だったという説が挙げられている注 13)。

再利用された工期 1 の柱頭以外は、比較的簡素で滑らかな葉の彫 刻が施され、クロシェは少ない。アバクスには背面にも刳り型が施 されている。

以上の 4 つの工期を経て、身廊、内陣、袖廊の大部分が完成し、 トリフォリウムはその全体が完成した。その後も近代まで側方祭室 の建設、塔の崩壊と再建等、改変や修復が随時行われたが、トリフオ リウムとは関係が薄いためここでは確認しない。

\section{3. 技術的特徴の分析}

前章で 4 つの工期とトリフォリウム内の切れ目が明確になったの で、本章では各工期における技術的特徴を整理する。

\section{3-1. 石積みの特徵}

ラン大聖堂のトリフォリウムは迫石によるアーチ、小円柱、板石 による規則的な天井、不規則な床（立面にコーニスとして現れる板 石はトリフォリウム背後の壁まで到達しておらず、板石のない部分 は粗く小さな石が多い）からなる。その全体的な構成は全工期を通 じてほぼ変化しない。しかし小円柱の部材の一体成形や、アーチの 迫石の数において工期ごとの差異が認められる。
通常トリフォリウムの小円柱の柱頭、柱身、柱基は別々のブロッ クで成形され、施工時にモルタルや鉛、金属の太柄等を用いて接着 されるが、一部の現場ではそれらを 1 個のブロックで実現すること があった。ラン大聖堂においても、柱頭と柱身が一体のブロックで 構成されている小円柱が見出された（ただしアバクスは別のブロッ クからなる）注14)。小円柱全体においてそのような構法の占める割合 は各工期で異なり、以下のように整理される。

>工期 $1 \cdots$ トリフォリウムの小円柱の柱頭と柱身は全て独立した 別々のブロックでつくられている。ベイ端部の小円柱の柱身はアン・ デリのモノリスであり、隣接するピアの組積とは独立している。た だし柱頭と柱基はピアの組積と一体である（Fig.9）。

>工期 $2 \cdots$ 袖廊西側ではおよそ 2 つひとつの割合で、柱頭と柱身 が単一のブロックに一体でつくられている。身廊のベイ 11 では約半 分、ベイ $8 \sim 10$ では全ての小円柱において、柱頭と柱身は一体で ある。さらに、身廊のベイ端部においては、柱頭、柱身、柱基およ び当該小円柱が取り付いているピアの一部までもが、ひとつのブロッ クでつくられている (Fig.10)。

>工期 $3 \cdots$ 全ての小円柱において柱頭と柱身が一体である。

>工期 $4 \cdots$ およそ $20 \%$ ～ $25 \%$ の割合で柱頭と柱身は一体である。 ベイ端部の小円柱の柱身は、再び隣接するピアとは独立したアン・ デリのモノリスで構成されている。

以上のように、工期 2 と 3 では柱頭と柱身が一体である割合が高 い。特に両工期の境目であるべイ 7 と 8 の間で変化が見られないこ とから、工期 2 の間に一体構築が現場で一般化し、続く工期 3 では 最初から一体構築で建設されたのではないだろうか。一方で、2 と 3 の間には石積みの切れ目があり、迫石の大きさも異なっている。現 場組織が大きく変化したかどうかをこれらの観察からのみ判断する ことは難しい。工期 3 では工期 2 で使われた技術を取り入れて工事 が進められたという可能性も考えられる。

また、トリフォリウムのアーケードのアーチは要石のない $6 \sim 10$ 個程度の迫石からなるが、その数には工期によって若干の変化があ る。工期 1 と 2 の部分では $8 \sim 10$ 個の比較的小さい迫石が多くみ られるのに対し、工期 3、4 では $6 \sim 8$ 個の迫石が多かった（Fig.11）。 

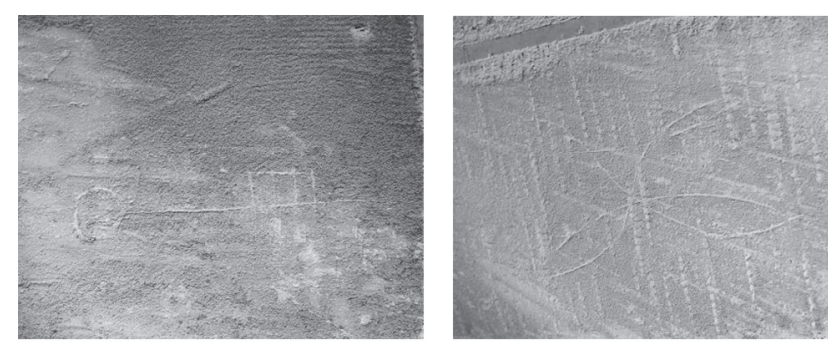

Fig.12 Masons' marks

もちろん迫石の数はベイ幅およびアーチの形状 (半円/尖頭)によっ ても影響される。ヴォールトを受けるシャフトの束が工期 $2 \sim 4$ で はやや分散して配置されているので、ベイ幅（ピア間の内法）は工 期 1 のベイ幅に比べ 4 ～5\%減少している ${ }^{\text {注 }}$ 。 アーチが尖頭形である。とはいえ、工期 2 と 3 ではベイ幅がほぼ同 じでいずれも尖頭形アーチからなるにもかかわらず、迫石の数は異 なる。加えて、一つの迫石の大きさも工期 $3 \cdot 4$ の方が工期 $1 \cdot 2$ に 比べて大きい傾向が認められる。これらのことから、迫石の数には 工期の違いが反映されているとみな寸ことができる。

なお、12 世紀の半円形アプスの内陣では、トリフォリウムのアー ケードの迫石は湾曲していたはずなので、工期 4 での再利用はされ なかったと思われる。

\section{3-2. 職人のサイン}

内陣のベイ $13 \sim 15$ および袖廊東側、すなわち工期 1 に相当する 部分において、トリフォリウム背後の壁に職人のサインが発見され た(Fig.12)。職人のサイン (mason's marks / signes lapidaires(仏)) とは、部材加工時に石材のブロックに描かれた特定の形の図形のこ とである注16)。その役割は多様であるが、一般には報酬の支払いの目 安とするために各職人が自分の仕事の目印として描いたものと解釈 できる。報酬の計算方法の違いや現場の組織の仕方によっては、こ のようなサインがまったく使われない場合もある。

身廊の北東すなわちべイ N8～N11にもいくつかそれらしきもの が見受けられたが、不明瞭であった。身廊南側、およびベイ 7 以西 ではサインは見当たらなかった。

明瞭に確認されたサインは、ベイにつき多くても 4 つ程度であっ た。多くの石が修復で取り替えられてしまっていることも少なさの 一因であろう。形状は単純で、幾何学模様、具象的な鍵や星、 $\mathrm{A}$ や $\mathrm{S}$ などの文字が大半であった。彫刻としての質は高くはなく、くぼ みの断面に特定の形状は認められない。

\section{3-3. 横材用の穴}

身廊のベイ $5 \sim 11$ および袖廊の西側において、トリフォリウム の背後の壁に十数センチメートル四方の四角い穴（Fig.13）が確認 される。これは横材用の穴 (trou de boulin (仏) ) とみられる。横 材用の穴とは、建設時に足場や型枠の木組みを壁に固定するために 使われる、横材を差し込むための穴である ${ }^{\text {i } 17) 。 ~}$

穴はベイにつき $2 つ 、$ 背後の壁の最下部に開けられており、貫通 していない。穴の形状は整った正方形に近く、建設後に設けられた とは思われない。工期 2 と 3 の部分にのみ横材用の穴があるという ことは、工期 1 と 2 の間、および 3 と 4 の間で使われる技術が変化

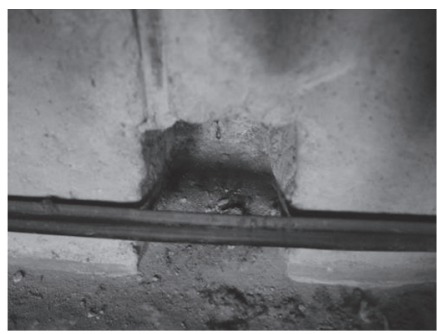

Fig.13 Trou de boulin (putlog hole)

したということを意味する。

\section{4. 小円柱の柱身と柱礎の高さの規則性・不規則性}

全ての小円柱の柱身と柱礎の高さを測定し、その規則性・不規則性、 工期間の寸法の差異を分析する。ほぼ全ての小円柱の柱身の高さは 84 〜 $89 \mathrm{~cm}$ である(Fig.14)。内陣と袖廊東側の測定值を平均すると、 $86.4 \mathrm{~cm}$ (北)、 $85.9 \mathrm{~cm}$ (南) である。工期 1 と工期 4 の柱身の間に 大きな変化は見受けられなかった ${ }^{\text {注 } 17)}$

身廊と袖廊西側をみると、工期 3 に当たるべイ 7 以西では工期 2 のベイ 8 以東よりも柱身がやや低い。すなわち、北側では工期 3 側 が $85.7 \mathrm{~cm}$ に対し工期 2 側が $89.4 \mathrm{~cm}(+3.7 \mathrm{~cm})$ 、南側では同じく $86.0 \mathrm{~cm}$ に対し $87.5 \mathrm{~cm} （+1.5 \mathrm{~cm} ）$ である。反対に、柱礎は工期 3 側 のほうが高く、北側の工期 3 側では $14.5 \mathrm{~cm}$ 、工期 2 側では $10.5 \mathrm{~cm}$ $(-4 \mathrm{~cm})$ 、南側では工期 3 側で $12.9 \mathrm{~cm}$ 、工期 2 側で $10.8 \mathrm{~cm} \quad(-2.1 \mathrm{~cm})$ となっている。柱身と柱礎の高さを合計すると、北側では工期 3 側 で $100.2 \mathrm{~cm}$ 、工期 2 側で $99.9 \mathrm{~cm}$ 、南側では工期 3 側で $98.9 \mathrm{~cm}$ 、工 期 2 側で $98.3 \mathrm{~cm}$ となり、誤差は $2 \mathrm{~cm}$ 程度に収まる。調査では柱頭 や柱基剞り型の高さを計測しなかったため断定はできないが、小円 柱が柱頭から柱基まで一体で作られているとすれば、部材の加工時、 全体の寸法さえ一定であればその内部の配分は比較的自由であった という可能性も考えられる。

もし石材の寸法や規則性に大きな変化があれば、それは部材の寸 法基準や加工精度の変化を意味し、現場組織の変化を知る手がかり になるが、ラン大聖堂のトリフォリウムではそのような大きな変化 は見受けられないという結果になった。

\section{5. 結論}

石積みやトリフォリウム内部にみられる建設技術の変遷等から判 断して、工期 1 および 3 の後には建設手法の変更を伴う現場組織の 変化があったと思われる。サインがほぼ工期 1 の部分にのみ存在す るという事実は、これらの部分が建設された後に現場の組織が大き く変化したことを証言している。ただし工期 2 にあたる身廊北東部 にも、不明瞭で数も不十分ながら少量のサインがあり、内陣完成か ら身廊着工までの間に現場組織の大きな変化があったかどうか、サ インからのみでは確実には判断できない。サインがある工期 2 中の ブロックは工期 1 の段階で加工されて施工されぬままストックされ ていたという可能性もある。ただ、横材用の穴や一体構築の柱が工 期 1 では皆無であることから、工期 1 と 2 の間で大きな変化があっ た可能性が高いと考えられる。

工期 2 と 3 では石積みの切れ目や小円柱の寸法の変化はあるもの の、背後の壁の横材用の穴、柱頭と柱身の一体構築などの技術的な 

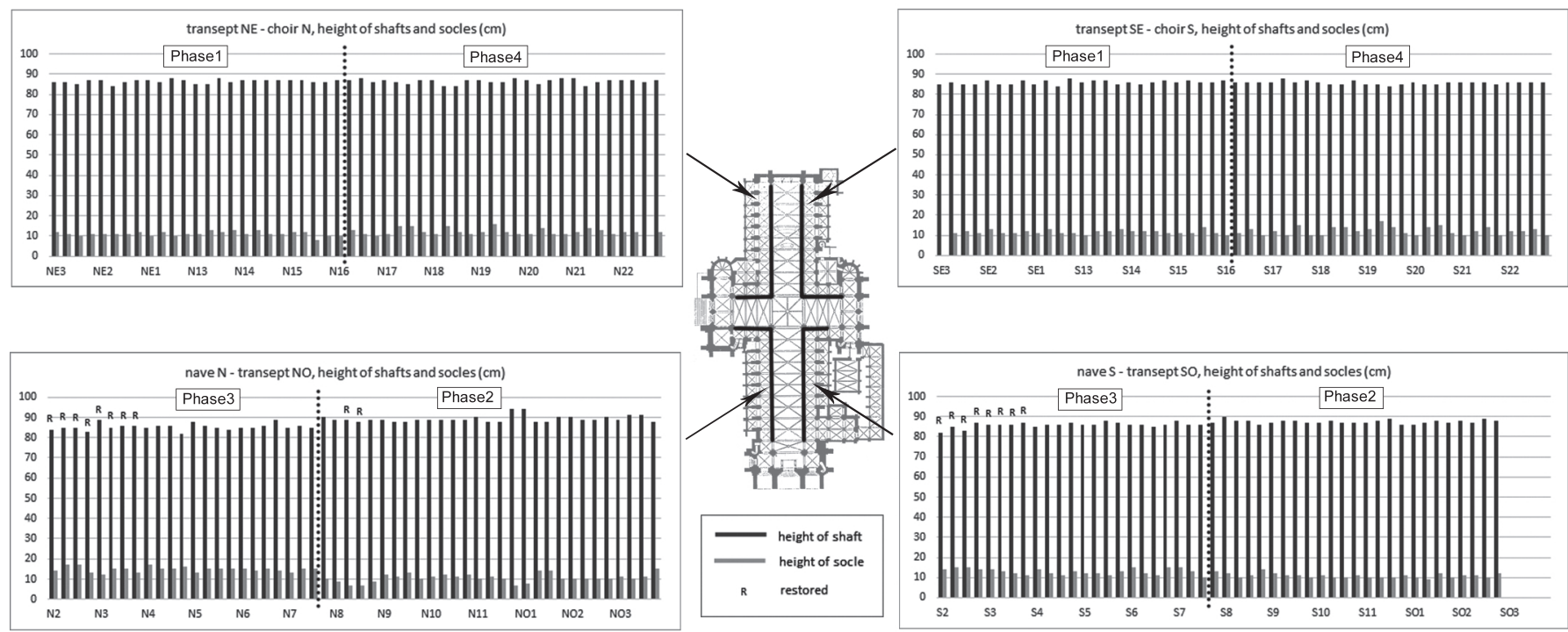

Fig.14 Height of shafts and socles of the triforium

特徴が共通しており、現場組織が大きく変化することなくある程度 一貫した方法で建設が進められたようだ。工期 4 では工期 3 にあっ た横材用の穴が見られなくなり、柱頭と柱身の多くは再び別々に加 工されるようになることから、工期 3 とは異なる手法を持つ人物が

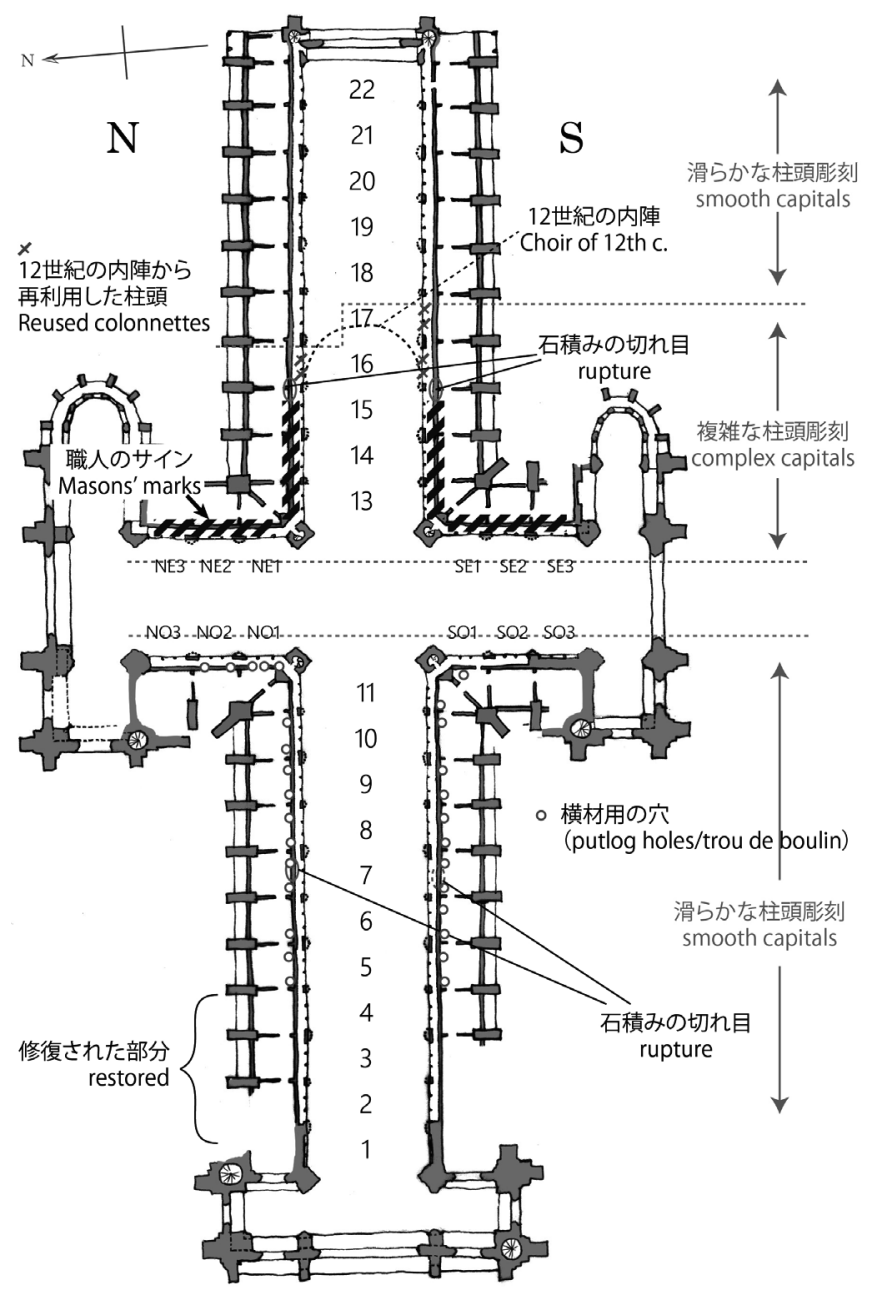

Fig.15 Plan at the height of the triforium showing the observations made in the article (by author)
工事を指揮したと考えられる。

ラン大聖堂は、半世紀以上を費やして建設されたにもかかわらず ほとんど同じデザインを保っているので、最初に定められた立面が 後の工事でも尊重されたという点がこれまで強調されてきた。しか し以上の分析によって、実際には現場組織の明確な変化があったこ とが判明した。無論、長い建設期間に職人の交代や現場組織の変化 があったことは自明であるし、交代が工期の切れ目においてであっ た可能性が高いのも自然である。しかし本稿ではそれを単なる可能 性にとどめず、実証的かつ具体的に論じることができた。トリフォ リウムの技術的なディテールにはそれぞれの工期独自の技術や手法 が存在し、それがゴシックの建設現場や職人に関する理解を深める ための手がかりともなる。このように、トリフォリウムの調查・分 析は、地上からの観察では見えていなかった建設現場の内幕に光を 当てることができるという点で、ゴシック建築の個別研究や中世の 建設技術の解明に寄与寸る可能性を秘めている。

小円柱の寸法のばらつきをその他の建築のトリフォリウムと比較 することによって、ランでの部材の寸法の標準化・規格化の程度を より媣く検証することができるであろう。今後、ラン大聖堂以外の ゴシック教会堂建築のトリフォリウム調査を行い、分析を進めたい。

\section{謝辞}

調査に当たってはラン市美術館館長のレミ・バザン氏と補佐のモ ルガン・レック氏にご賛同とご協力をいただきました。また、本研 究は JSPS 科研費 JP14J10678 の助成を受けたものです。それぞれ 謝意を表します。

注

注 1) 主要な既往研究としてはP.エリオ（Héliot）による一連の論文や、 Lheure Michel, Le triforium, Paris, Picard, 2012 が挙げられるが、いずれ もトリフォリウムの内部調查は行っていない。個々の建物の個別研究等で 散発的に立ち入られることはあるが、詳細な調查が行われることは非常に 稀である。

注 2) Bouxin Auguste, La Cathédrale Notre-Dame de Laon, historique et description, Laon, impr. de A. Cortilliot, 1890 は参事会の記録や司教の 人物伝等の一次史料を主な手がかりとして、ゴシック期以前の建物から 
現在の建物の修復に至るまでの主要な年代を整理した。内陣から身廊西 側に至るまでの建設段階の解明は、彫刻やヴォールトの形状といった様 式的特徴の変化を主な論拠としている。 R. キングの未完の博士論文に基 づく W. W. クラークの著作 (Clark William W. and King Richard, Laon Cathedral, Architecture, 2 vol., Courtauld Institute Illustration Archives, Companion Text 1 et 2, Harvey Miller Publishers, Londres, 1983-1987) は、彫刻のより厳密な観察によって各工期で建設の進んだ方向を見定める とともに、石積みの変化などのより考古学的な観点も用いて建設段階を 分析している。同時期の Fernie Éric, “La fonction liturgique des piliers cantonnés dans la nef de la cathédrale de Laon ", Bulletin monumental, 1987, vol. 145, no 3, p. 257-266 は、身廊の東側の大アーケードにのみ存 在する小円柱に取り囲まれた柱が単なるデザインではなく儀式的役割によ る意図的なものであるとの仮説を提出し、大聖堂の内部空間の使われ方に 新たな見方を提供した。Kimpel Dieter et Suckale Robert, L'Architecture gothique en France : 1130-1270, traduit par Françoise Neu, Paris, Flammarion, 1990 (originally published in Germany, 1985), p. 193-210 では、袖廊のトリビューンの西側で東側よりも石材が大きくなる傾向が認 められることから、工事の進捗に伴い機械に頼ることが多くなったので はないかという見解を述べるなど、建設の観点が導入されている。SaintDenis Alain, Plouvier Martin et Souchon Cécile, Laon, la cathédrale, Paris Zodiaque, 2002 は建設史、修復史、彫刻、同時代の建築におけるラ ン大聖堂の位置づけ等を丁寧に記述するだけでなく、各祭壇の名称や敷石 に埋め込まれた墓石の位置に至るまで、ラン大聖堂の建築的・歷史的・儀 式的側面を逐一記録している。

注 3）建設現場では石切職人、石工、モルタル工、彫刻家など多数の役職か らなる職人たちが働いていた（Cf. Du Colombier Pierre, Les chantiers des cathédrales : d'après les trésoriers, les architectes, les maçons, les sculpteurs, les textes, les miniatures, les vitraux, les sculptures, Paris, éditions A. et J. Picard et Cie, 1973, p. 41-47)。彼らは必ずしも特定のメ ンバーからなる「チーム」として現場から現場へ渡り歩いていたとは限らず、 現場の構成員はある程度流動的であっただろう。本稿における「現場組織 の変化」とは、現場で働く職人の多くが入れ替わる、あるいは現場を統率 する人物が変化することを示している。それは石の積み方や寸法、報酬の 支払い方法等の技術的特徴の変化に見て取れると考えられる。

注 4) Mérimée Prosper, "Restauration de la cathédrale de Laon," Revue archéologique, 5e année, 1, 1848, p. 13-18 ; Saint-Denis et al., op. cit., p. 116-124. (C. Souchon)

注 5) Clark and King, op. cit., p. 32-33. ここでは石積みの切れ目や様式的特徵 によって判断される一続きのまとまりとして「工期」（phase）を定め、そ れぞれの切れ目で長い工事の中断や断絶があったか、現場組織の変化があっ たかは考慮しない。

注 6) Bouxin, op. cit., p. 35.
注 7）直線部のベイ $13 \cdot 14$ 間のピアと比較するとその違いが明白である。こ れらの痕跡は先行研究でも指摘されている。大アーケードに見られる痕 跡としては、アバクスが湾曲していること、円柱が再利用されているこ と、ベイ 15 の東端で柱基がわずかに湾曲していることなどが挙げられる。 Saint-Denis et al., op. cit., p. 194 ; Sandron, op. cit., p. 192. 半円形アプス 部分ではアバクスを湾曲させることが一般的に行われた（パリのノートル =ダム大聖堂、ノワイヨン大聖堂など)。

注 8) クラークとキングも再利用された彫刻について同様の見解を述べている。 Clark and King, op. cit., p. 48.

注 9) Bouxin, op. cit., p. 36 .

注 10) Clark and King, op. cit., p. 38, 40-42.

注 11）キンペルらはこの工期が西から始められた可能性も否定しない (Kimpel et Suckale, op. cit., p. 487, n. 42) が、クラークとキングは柱頭の変化から して東から進められたことは明白だとしている(Clark and King, op. cit., p. 46)。

注 12) Bouxin, op. cit., p. 36. サンドロンによればこの記録は参事会の採掘 権を確定するためのものであって、この頃既に工事が開始していた可能 性も考えられるとしている。Sandron Dany, Picardie gothique. Autour de Laon et Soissons: L'Architecture religieuse, Paris: Picard, 2001, p. 189-193.

注 13）ファーニーは、改築前は建築上の内陣（交差廊より東の部分）だけで なく身廊の一部までが内陣の一部として使われていたのではないかとの見 方を示している。Fernie,op. cit., p. 257.

注 14）柱身と柱基の間は接合部の有無の判断が難しいため、柱基の一体構築 は考慮していない。柱頭と柱身の間で接合部の有無が不明瞭な箇所に関し ては、一体ではないとしている。

注 15) 厳密には、シャフトは工期 2 の袖廊西側部分でも工期 1 と同様に密集 している。しかし袖廊のベイ幅は隣接するヴォールトのリブの太さ等によっ て不規則であるため、考察から除外している。内陣や身廊の交差部に隣接 するべイも同様の理由から除外した。

注 16) 職人のサインに関する文献は膨大にあるが、概説的で要点を押さ えた文献としては Esquieu Yves et al., "Les signes lapidaires dans la construction médiévale : études de cas et problèmes de méthode ", Bulletin monumental, 2007, vol. 165, p. 331-358 が挙げられる。

注 17) Cf. Reveyron Nicolas, « Typologie, structure et implantation du trou de boulin dans son rapport à l'échafaudage médiéval ", Archéologie du Midi médiéval, 1994, vol. 12, no 1, p. 79-98.

注 18) 柱身、柱礎それぞれの実測值の標準偏差は、工期 $1 \sim 4$ の順に以下の とおりであった。柱身: 0.99, 1.61, 1.30, 1.05。柱礎 : 1.06, 1.48, 1.70, 1.76。 (写真は全て筆者撮影)

(MAP: France, Ministère de la Culture, Médiathèque de l'architecture et du patrimoine, dist. RMN-GP) 


\section{THE CHANGES IN ORGANIZATION OF THE WORK SITE AT THE NOTRE-DAME CATHEDRAL OF LAON}

The importance and the possibilities of studying the triforium

\section{Aya SHIMAZAKI ${ }^{* 1}$}

${ }^{* 1}$ Research Assist. Staff, Dept. of Architecture, Graduate School of Engineering, The University of Tokyo, Dr.Eng.

Laon Cathedral is distinguished by its unchanged elevation despite its relatively long period of construction (c. 1155-c. 1230). The triforium retained its three-arcaded composition. It is evident that the organization of the work site changed several times during the construction. However, existing analysis have not paid attention to this problem. This paper aims to answer this question through a study of the triforium.

The triforium, passageway inside the thickness of a Gothic wall, has been rarely studied. This is regrettable because the triforium is rich in information. Its complicated composition and the diversity of its elements sometimes reflect the ruptures of construction or the changes in organization of the work site.

I investigated the triforium of Laon Cathedral in the following procedure:

1. Make clear the ruptures in the construction on the basis of the masonry and the capital sculptures.

2. Examine the techniques of construction (the masonry, the mason's marks and the putlog holes (trou de boulin)).

3. Measure the heights of the shafts and the plinths of all the colonnettes. Analyze their differences between each construction phases and see their regularity/irregularity.

The study suggests that the organization of the work site seem to have changed after the first and the third phases: The first phase is characterized by its naturalistic style of the capital sculptures and the usage of the mason's marks; The originality of the second and third phases are the presence of the putlog holes (which testifies the usage of cantilevered scaffolding) and the construction of the shaft and the capital in the same block; These techniques can not be seen in the forth phase.

Despite its unchanged design throughout the whole construction campaigns, there were several changes in organization of the work site. Studying the triforium can contribute to the monographic research on Gothic monuments. 